\title{
131 複数振動子による吊橋振動
}

\author{
Suspension Bridge Vibration due to Oscillators

$\begin{array}{lll}\text { O正長嶺 拓夫 (埼玉大) } & \text { 正森 博 輝 } \\ \text { 学茂木 知之 } & \text { 正 佐藤勇一 }\end{array}$

Takuo NAGAMINE, Saitama University, 255 Shimo-okubo, Sakura-ku, Saitama-shi, Saitama Hiroki MORI, Saitama University Tomoyuki MOTEGI, Saitama University Yuichi SATO, Saitama University

In this paper, we describe the coupled vibration of oscillators mounted on a plate hanging on four strings and investigate the effects of damping on such vibration. From the experimental and numerical simulation results, the following result was obtained. There is an area of parameters, which produce the small amplitude of the support vibration.

Key Words: Coupled Vibration, Oscillator, Natural Frequency, Phase-Locking, Entrainment, Synchronization

A1. はじめに

複数の自厉振動子が互、影響を与え合う場合，それぞれの振 動子のもつ周期が若干異なっていても，周期が一致する同期 現象が知られている. 17 世紀の半ばに細いはりに掛けられ た二つの振子時計の周期が一致する現象としてホイヘンスに

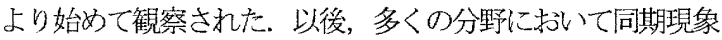
は観察されている(1).

同期現象による問題としては，多数の歩行者の歩行と歩道 橋の横摇れが同期し大きな振動を引き起したことがある. Fujinoらは実験的な検討を行い，歩行により橋に横摇れが生 し，その摇れにより多くの歩行が引き込まれて同期し，さら に大きな橋の振動を起すことを報告している(2). 松久らは身 体のリズム生成機構である神経振動子と歩道橋の横振動の関 係を引き込文現象として梌討している(3)

著者らは複数の振動子と支持采が連成振動することにより 大きな振動が起ることを防止する目的で研究を行っている. 本論文では，系によって吊られた支持系に複数の振動子を載 せた場合の連成振動につい検討を行った. 全ての振動子が そろって振動し支持系が大きく振動寸る場合と振動子が互、 の振動を打消し合い支持系の振動が非常に小さい場合がある。 ここでは、大きな振動が起る場合、減衰を与えてその振動に 与える影響を調べたので報告を行う。

\section{A2 実 験}

図A1 は実験装置の概略を示したものである４４本の糸で 吊られた台の上に振動子が載せられている．糸は，横力向 （ $x$ 方向）にのみ台が振動するように張ってある. 台の固有 振動数 $p$ は系の長さLによる. 台の減衰比ら てあるダンパで調整している. 台の固有振動数 $f_{p}$ を $15 \mathrm{~Hz}$ 〜 $4.0 \mathrm{~Hz}$ 範囲で実験を行った. 振動子の固有振動数は約 2.67

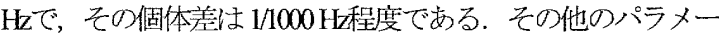
夕に関しても個体差は非常に小さく，各振動子はほぼ司一な 特性である。

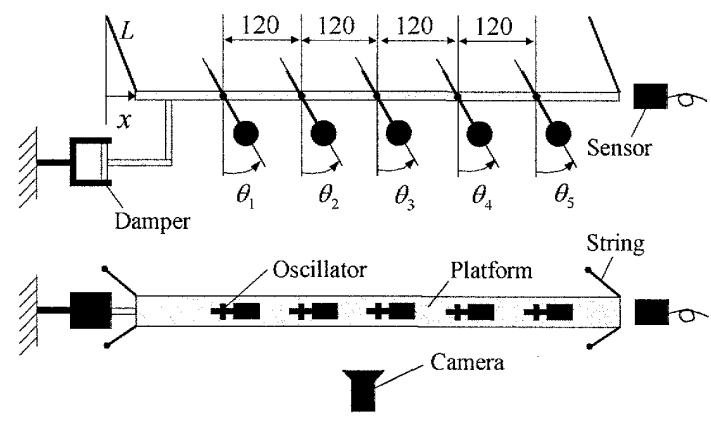

Fig. A1 Experimental apparatus

台の質量 $M \mathbb{R}$ 减衰比らpを設定し，それから台の系の長さ $L に$ より台の固有振重数安設定した，その後，初期条件として台を 静止させた状態㘦，全ての振動子の初期角度を $42^{\circ}$ に設定 し振動を開始させた．振動を開始させてから十分に时間が経過 した後に計測を行った．計測は非接触変位計とCCDカメラの 画像を用いて行い，振動子々台の変位を計測した，なお今回の 実験では5台の振動子 $(N=5)$ を用いた。 これらの実験により，

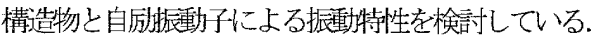

\section{A3. まとめ}

吊橋状の構造物に載せられた自励振動子による振動特性に ついて，実験および計算より検討を行った，それにより以下 のことが明らかとなった。

構造物の上に配置された自励振動子が同位相で同期寸るこ とにより構造物に大きな振動が生じるが，その同期現象は台 の固有振動数 $f_{p}$ に影響老受け， $f_{p}$ が自厉振動子の振動数より も高いとき，この同位相同期が起らない領域（大きな振動が 発生しない領域)があることを明らかにしている. 


\section{1. はじめに}

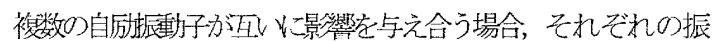
動子のもつ周期が若干買なっていても，周期が一致与る同期 現象が知られている.17 世紀の半ばに細いはりに脚けられ た二つの振子時計の佶期が一致する現象ししてホイヘンスに より始めて観察された. 以後, 多くの分野に执、て同期現象 以観察されている(1)

同期現軞による問題としては，多数の步行者の步行と歩道 橋の獚摇れが同期し大きな振動を引き起したことがある。

Fujinoらは実験的な検討を行い，歩行により橋に横摇丸が生 じ，その摇れにより多くの歩行が引き込まれて同期し，さら に大きな橋の振動を起すことを報告している( ${ }^{(2)}$ ，松久らは身 体のリズム生成機構である神経振動子と歩道橋の横振動の関 係を引き込み現象として検討している(3).

著者らは複数の振動子と支持系吕連成振動することにより 大きな振動が起ることを防止する目的で研究を行っている。 本諭文では，系によって吊られた支持系に複数の振動子を載 せた場合の連成振動について検討を行った. 全ての振動子が そろって振動し支持采が大きく振動する場合と振動子が互い の振動老打消し合い支持系の振動が非常に小さい場合がある. ここでは、大きな振動が起る場合、減衰を与えてその振動に 与える影響を調べたので報告を行う。

\section{2. 主な記号}

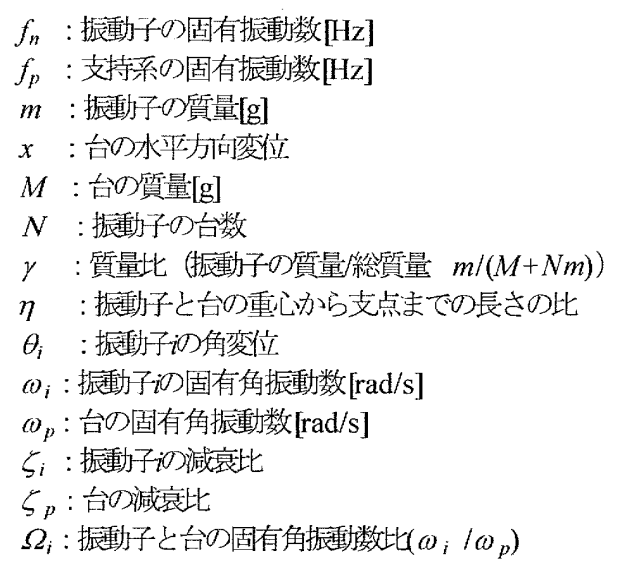

\section{3. 実 験}

$3 \cdot 1$ 実験装置 図 1 は実験装置の概略を示したもので ある.4本の系で吊られた台の上に振動子が載せられている. 糸は，横方向（ $x$ 方向）にのみ台が振動するよう，上方に広 がるように張ってある. 台の固有振動数 $f_{p}$ は系の長さLによ る. 台の減衰比とや，図1に示してあるダンパで調整してい る. 台の固有振動数 $f_{p}$ を $15 \mathrm{~Hz} \sim 4.0 \mathrm{~Hz}$ 範囲で実験を行った. また台の質量 $M$ を $1,3,5 \mathrm{~kg}$ ，減衰比 $\zeta_{p}$ を $0.002,0.01,0.03$ として 実験を行った。振動子は太陽電池によって駆動される小型の 自励振動子を用いている. 質量が約 $19 \mathrm{~g}$ で支点から重心まで

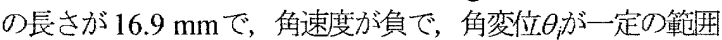
で駆動トルクが加わる. 振動子の固有振動数は約 $267 \mathrm{~Hz}$ で, その個体差は $1 / 1000 \mathrm{H}$ 程度である. その他のパラメー夕に関 しても個体差は非常に小さく，各振動子はほぼ同一な特性で ある.

3.2 実験方法 台の質量 $M$ 队减衰比 $\zeta_{p}$ を設定し，乙れ から台の系の長さしにより台の固有振動数を設定した：その
後，初期条件しして台を静比させた状態から，全ての振動子 の初期的度を $42^{\circ}$ に設定し振動を開始させた，振動党開始 させてから十分に時間か絟過した後 (10分程㔀)の約7分間 計测を行った，計測は非接触変位計とCCDカメラの画像を 那いて行い，振動子と台の変位を棓測した。 な㧍今回の实験 では5台の振動子 $(N=5)$ を用いた。

\section{4. 解 析}

4・1 運動方程式 台の振㡖は小さく，鉛直方向の変位 成分は十分小さいとして無視している，振動子仗剛体として 扱い，駆動力は一定角変位内で与えられるものとすると運動 方程式は以下の上うに表わすことができる。

台：

$$
\begin{aligned}
& \frac{d^{2} x}{d \tau^{2}}+2 \varsigma_{p} \frac{d x}{d \tau}+x \\
& =\gamma \eta \sum_{i=1}^{N}\left\{\left(\frac{d \theta_{i}}{d \tau}\right)^{2}\left(\sin \theta_{i}-x \cos \theta_{i}\right)-\frac{d^{2} \theta_{i}}{d \tau^{2}}\left(\cos \theta_{i}+x \sin \theta_{i}\right)\right\}
\end{aligned}
$$

振動子：

$$
\begin{aligned}
& \frac{d^{2} \theta_{i}}{d \tau^{2}}+2 \varsigma_{i} \Omega_{i} \frac{d \theta_{i}}{d \tau}+\Omega_{i}^{2} \sin \theta_{i} \\
& =-\Omega_{i}^{2} \frac{d^{2} x}{d \tau^{2}} \cos \theta_{i}-T_{i} \cos \theta_{i}, \quad(i=1 \sim N)
\end{aligned}
$$

ここで, 式 (2) のT駆動トルクを意味し，角速度が負 $\left(d \theta_{i} / d t<0\right)$ で，角变位 $-4.4 \mathrm{deg}<\theta_{i}<14.8 \mathrm{deg}$ の範用て駆 動トルクが加わるものとした.これらの運動方程式を数值積 分して時刻榞店答を求めた。

\section{5. 結果および考察}

$5 \cdot 1$ 実験結果 台の質量を $3.0 \mathrm{~kg}(\gamma=0.0058)$ に設定し, 台の固有振動数 $f$ を $15 \mathrm{~Hz} \sim 4.0 \mathrm{HZ}$ 範囲の実験結果を示市. このとき, 台の減衰比 振動数 $f_{p}$ を $21 \mathrm{~Hz}$ 亿設定した時の実験結果である. (a)は振動 子の角変位および台の水平方向変位の波形，(b)泣振動子間の 位相差の時間変化を示している. 図 2(a)より，全ての振動子 は同位相で振動しており，台の振幅が約 $1 \mathrm{~mm}$ であることが 分かる. (b)上り十分長い時間，各振動子間の位相差梳注 0 degを保っている，つまり同位相同期をしていることが分か る. またここの時振動子と台の位相差は約 $180 \mathrm{deg}$ こなってい た.ここでは，このような同位相同期のタイプをTypel と呼 ぶことにする.

台の固有振動数 $f_{p}$ をさらに高い $28 \mathrm{~Hz}$ に設定し, 行った実 験結果を図 3 に示す。前記の実験結果と同様に全ての振動子 は同位相で同期しておう，台子と台の位相差はほぼ $0 \mathrm{deg}$ と なっている.このような同位相同期のタイプをType2 と呼ぶ ことにする. 実験を行った結果，全ての振動子が同位相で同 期すると台が加振されて大振動を生じることを確認した，振 幅は約 $1 \mathrm{~mm}$ である. 同位相同期には振動子々台の位相差が $0,180 \operatorname{deg}$ のタイプあり，それらは台の固有振動数 $f_{p}$ に影響 


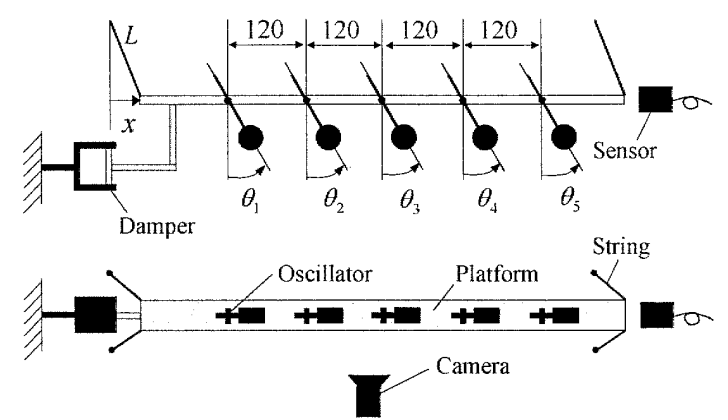

Fig. 1 Experimental apparatus

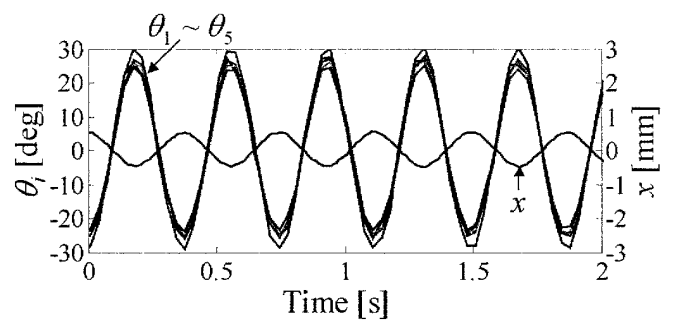

(a) Time waves

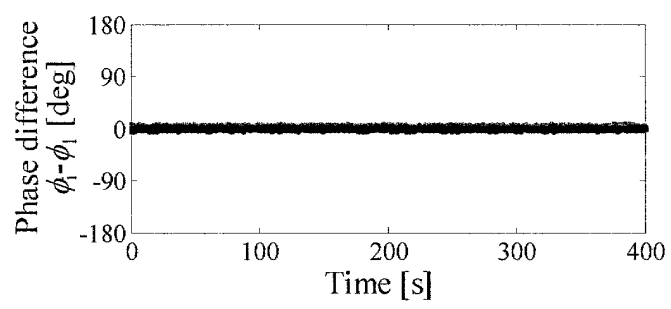

(b) Phase difference between $\theta_{1}$ and $\theta_{i}$

Fig. 2 Experimental result $\left(\gamma=0.0058, f_{p}=2.1 \mathrm{~Hz}\right)$

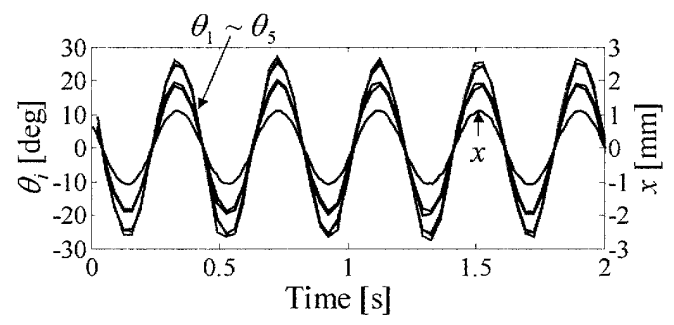

(a) Time waves

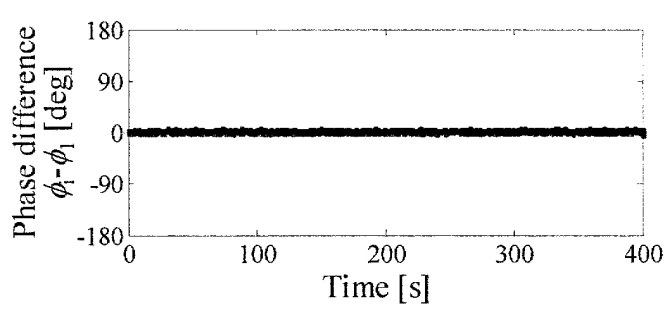

(b) Phase difference between $\theta_{1}$ and $\theta_{i}$

Fig. 3 Experimental result $\left(\gamma=0.0058, f_{p}=28 \mathrm{~Hz}\right)$

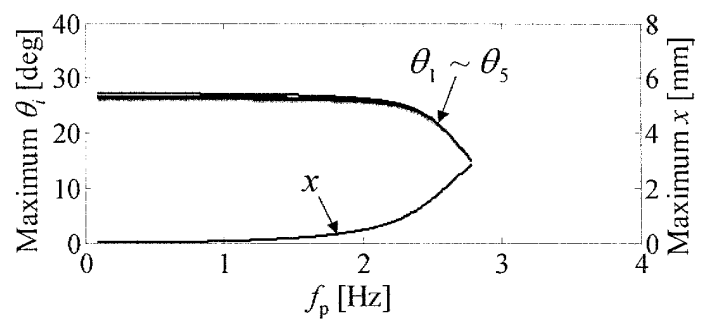

(a) $f_{p}$ and $\theta_{i}, x$

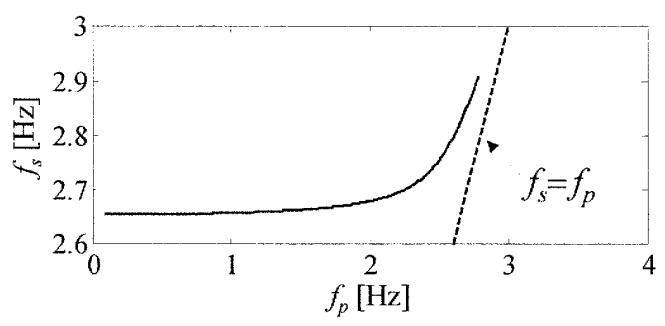

(b) $f_{p}$ and $f_{s}$

Fig. 4 Calculated result $\left(\gamma=0.0058, \zeta_{p}=0.002\right)$

を受けることも分かった $f_{p}$ をさらに高くすると同位相同期 が起らず，台の振幅は小さくなる.

$5 \cdot 2$ 計算結果 実験結果加巨全ての振動子北同位相で 同期することで台が大振動を生じることが分かったので，前 記の運動方程式(1)と(2) 老用いて数值計算を行い，上記のよ うな同位相同期の周期解を求めた．計算に用いた滅衰比は前 記の実験条件に近い值の 0.002 とした. 図 4 は台の質量が 3.0 $\mathrm{kg}(\gamma=0.0058)$ におけるTypel の同位相同期の周期解を示してい る. (a)主振動子と台の振幅を台の固有振動数 た図であり，(b)は同期時の振動数 $f_{s}$ を台の固有振動数 $f_{p}$ に対 して示した図である. 害線で示されている部分はその解が安 定解であることを意味している. 計算は $0.1 \mathrm{~Hz} 4.0 \mathrm{~Hz}$ の範囲 で行った. なお，周期解が途中で無くなっている部分に関し ては，実験に用いた自励振動子の特性によるものなので，場 合によっては， $f_{p}$ がもっと高い領域に安定な周期解が存在 寸る可能性がある. 図 4(b)上り，台の固有振動数 $f_{p}$ を高くし ていくと同期振動数が台の共振ライン $\left(f_{s}=f_{p}\right)$ に近ついていく ことが分かる. それによって，図 4(a)を見ても分かるように 振動子は振幅が小さくなり，台は振幅が大きくなることが分 かる.

図 5 は台の質量が $3.0 \mathrm{~kg}(\gamma=0.0058)$ におけるType2 の同位相同 期の周期解を示している. 実線は安定解を, 破線は不安定解 をそれぞれ示している. 図 5 より，台の固有振動数 なっていくにつれて同期振動数吕台の共振ライン $\left(f_{\mathrm{s}}=f_{p}\right)$ 加ら 離れていき，台の振幅以徐々に小さくなっていくことが分か るが，そ扎でも比較的大きな振動となっている。 また， $f_{p}$ が $28 \mathrm{~Hz}$ 付近で周期解が安定解から不安定解になっている. $f_{p}$ が さらに高、領域にも周期解が存在するがそれらの解も不安定 解となっている。ここで，周期解が安定解から不安定解にな るあたりである一つの振動子の振幅が大きくなっているが, これはその周期解におる付る同期振動数が振動子の固有振動数 に近い值となり振動子が共振状態になるためと考えられる。 なお，図 5 も図 4 と同様に周期解が途中で無くなっている部 分があるが，こ扎穾験に用いた自励振動子の特性によるも のである. 


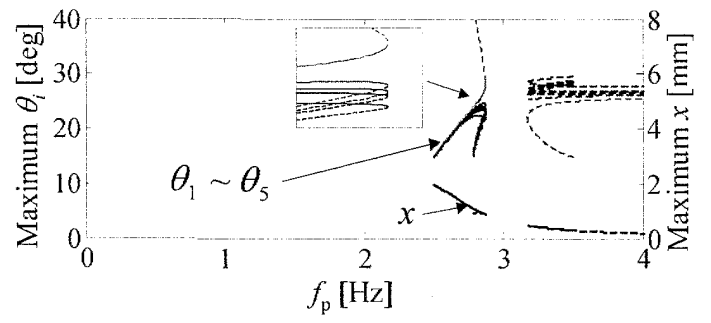

(a) $f_{p}$ and $\theta_{i}, x$

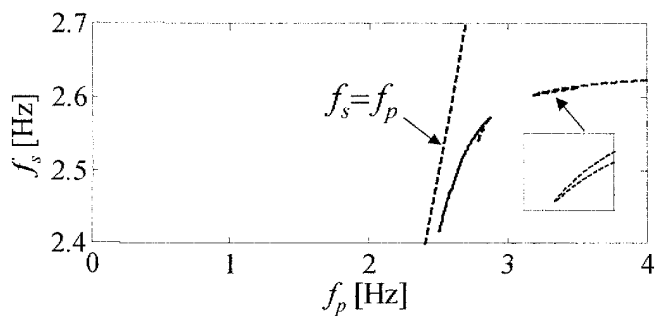

(b) $f_{p}$ and $f_{s}$

Fig. 5 Calculated result $\left(\gamma=0.0058, \zeta_{p}=0.002\right)$

図 6は数值計算により求めた安定な同位相同期解に対応す る周期解の質量比䛃対寸る存在領域を示している. 以降, 周期解は安定な周期解のみを指寸，縦軸に質量比 $\gamma$ を取り， 横軸には台の固有振動数 $\gamma$ は台の質量 $M$ を変えることで調整している。 つまり，図 6 の縦軸忧值が小さいほど台の質量 $M$ が大きいということを 意味している. 実線は台の質量 $M か ゙ 05,08,1,13,3,5,10 \mathrm{~kg}$ おりる同位相同期周期解(Type1 とType2)の存在領域を示して いる. 点線は $y$ 亿対する同位相同期周期解の存在領域の境界 (Type1 とType2)を示している. また，比較参考の為に図に同 じ条件の結果を(1)で示してある。

この図から，台の固有振動数 $f_{p}$ を高くすると同位相同期の 周期解が存在しない領域が女り，その領域は $\gamma$ を小さくて いくと搪大していくことが分かる. よってこのパラメータ領 域に系老収めることで，同位相同期による台の大振動を発生 させないようにできると言える。

図 7は数伹計算により求めた安定な同位相同期に刘心する 周期解の減衰比 $\zeta$ に対与る存在領域走示している. 縦軸に減 衰比 $\zeta$ p 横軸に台の固有振動数 $f_{p}$ を取っている. 減衰比を調 整すると図 7に示すような同位相同期の周期解方存在しない 領域があることが分からた．したがって，質量比とと台の固 有振動数 $f_{p}$ だけでなく，台の減衰比 $\zeta_{p}$ を調整することでも, 同位相同期による台の大振動を防止できることが分かる。

図 8 は振動子の台数Nに対する同位相同期周期解の存在領 域を示したものである. 台数Nが増えていくにつれて周期解 の存在領域が拡大していることが分かる．特に，Type2の周 期解の存在領域はf がって，前記の安全なパラメー夕領域は $N=5$ の場合のみで あり，同期現象による台の振動を防ぐためには，パラメータ $N$ 関しても検討しなければならない.

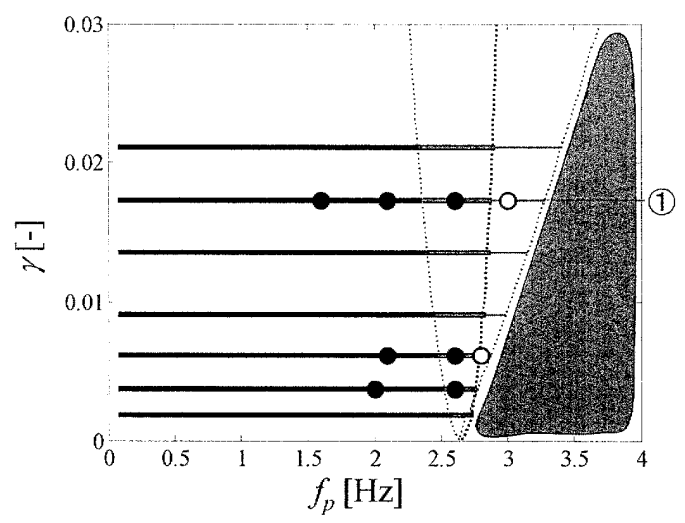

Cal. In-phase synchronization (Type1) : Cal. In-phase synchronization (Type2)

: Exp. In-phase synchronization (Type 1)

$\bigcirc$ : Exp. In-phase synchronization (Type2)

: Range of Non synchronization

Fig. 6 Range of in-phase synchronization vs $\gamma$ $\left(\zeta_{p}=0.002\right)$

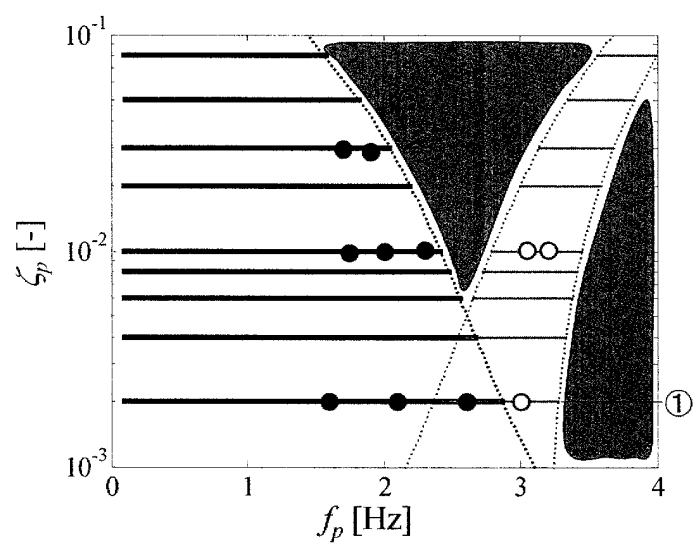

Cal. In-phase synchronization (Type1)

Cal. In-phase synchronization (Type2)

: Exp. In-phase synchronization (Type1)

$\bigcirc$ : Exp. In-phase synchronization (Type2)

图 : Range of Non-synchronization

Fig. 7 Range of in-phase synchronization vs $\zeta_{p}$ $(\gamma=0.0173)$ 


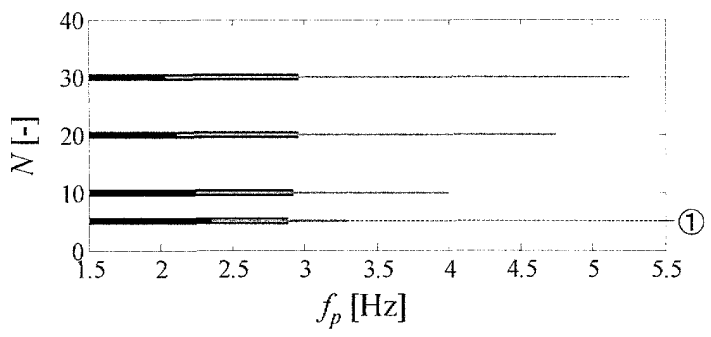

Cal. In-phase synchronization (Type1)

: Cal. In-phase synchronization (Type2)

Fig. 8 Range of in-phase synchronization vs $N$

$$
\left(\gamma=0.0173, \zeta_{p}=0.002\right)
$$

$$
\text { 6. まとめ }
$$

吊橋状の構造物に載せられた自厉振動子による振動特性に いて，実験および計算より検討老行った，それにより以下 のことが明らかとなった。
構造物の上に配置された自汸搌動子が同位相で同期するこ とにより構造物に大きな振動が生じるが，その同期現象は台 の固有振動数 $f$ に影響孝受け， $f$, 方自厉振動子の振動数より も高いとき，この同位相问期が起らない領域（大きな振動が 発生しない領域 があることを明らかとしている.

\section{文献}

(1) Pikovsky, A., et al., Synchronization, (2001), pp.1-7, Cambridge University Press.

(2) Fujino, Y., et al., Synchronization of Human Walking Observed During Lateral Vibration of a Congested Pedestrian Bridge, Earthquake Engineering and Structural dynamics, Vol.22(1993), pp.741-758.

(3) Matsuhisa, k., et al., Synchronization of Walking Rhythm by Lateral Vibration of Footbridge(in Japanese), Preprint of the Japan Society of Mechanical Engineers, No.03-7(2003), 458. 